\title{
RISK QUANTIFICATION FOR ENVIRONMENT ELEMENTS ALONG THE TRAFFIC ROUTE
}

\author{
Tomáš SASKA ${ }^{1}$
}

Research article

Abstract:
Currently the environment protection is a frequent topic in scientific groups. Many
themes from the environment area exist, which are discussed at conferences and scientific
events. One of these topics is surely dangerous substances transport risk assessment for
the environment. The following paper describes dangerous substances spreading at the
earth surface, the reach of their effect and their impact on single environment elements.
The result is a valuation, i.e. expression of value of affected natural environment and its
single elements.
Beywords:

\section{Introduction}

The pressure on risk assessment in many branches of human activities increases at this time more and more. It is also the case of dangerous goods transport. In this paper, we will put mind to risk assessment of dangerous liquids transport on the traffic routes and we will limit only to impacts of possible accidents for the environment along the transport routes.

At the beginning, it is necessary to say that all risk models, which describe real situation in human life, come from general risk model, which can be described by the following formula:

$$
R=P \cdot N
$$

where $R$ is risk, $P$ event occurring probability, $N$ event consequences.

So, it is reality simplification. There are many parameters for single equations by specific events assessment. These parameters are given by reflected boundary conditions.

\section{Materials and methods}

\section{Bandwidth exposure for liquids}

The bandwidth assessment of negative effects reach for liquids is more difficult than for gases. There are more scenarios of liquid spread and also wider spectra of potentially threatened environment elements. On the other hand the bandwidth is considerably smaller.

\section{Model principle}

The process of liquid spreading is spatially discretized using the square network. The time discretization is realized by time steps calculation. The cut of interest area is divided into square elements in the model by means of square network. The surface of each element is horizontal, homogenous in terms of all its parameters and it presents location whereon the processes are time steps simulated and the liquid balance is done.

The element altitude is primarily determined from altimetry data. In the database ZABAGED there are two types of data, by which the terrain morphology (contour lines and quoted points) is described. If some contour line passes through some element or there is some dimensioned point in this element, the elevation of this contour line or dimensioned point is associated to this element. The elevation for other elements is calculated by specially modified interpolation methods.

The liquid can flow always only to the neighbouring elements with lower surface level. If some lower surface level will be located in more elements, the flow will be divided. If no neighbouring element has lower surface level, then no flow will happen in that time step. It is concerned about element or elements group accordant with local terrain negative elevation which is first filled by liquid and then it may come to the overflow.

The important factor is the liquid capture on the terrain. Important thing is that each element has some small inequalities, which can be filled with the liquid. Also the vegetation cover can much increase specific surface for liquid capture. Both mentioned factors are determined on the basis of GIS data about

Technical University of Liberec, Faculty of Mechatronics, Informatics and Interdisciplinary Studies, Liberec, Czech Republic,tomas.saska@tul.cz 
cover type, which is located at each element (Saska et al., 2010). The minimal layer of captured liquid is defined for each surface type with liquid properties deliberation. When the liquid gets into the element, it has to reach this layer first. Only after this the liquid can spread to neighbouring elements.

During liquid flushing on the surface, its infiltration below the surface occurs as well. The liquid soil infiltration is expressed like the liquid decrease in the element per the time step. The evaporation solution is relatively simple. The quantity of evaporated substance per one time step is dependent on the liquid type primarily. We can ignore this process by many substances.

The calculation of liquid volume change in one time step is executed for each element in consequence of running physical processes. It is done by the liquid balance at the end of the time step and the state values are recorded. These values enter into the next time step like initial. Cumulated data about liquid decrease from each element are also monitored (evaporation, infiltration, move to surface waters) (Simmons and Keller, 2003; Simmons and Keller, 2005).

\section{Results}

\section{Threatened zone mapping}

For the presentation, the road E65 (I/10) between Loužnice and Plavy was chosen. The outflows of $30 \mathrm{~m}^{3}$ of diesel oil in $10 \mathrm{~m}$ steps were calculated in this sector. In each of the $10 \mathrm{~m}$ interval 3 potential outflow sources are supposed - on both roadsides and in the centre of the road. Totally spreading contours for more than 3000 pools were determined. The calculation was done deterministically with infiltration mean values.

On Fig. 1 there are displayed contours of single pools accordant with spilling of $30 \mathrm{~m}^{3}$ of diesel oil by the accident between Loužnice and Držkov. According to the large density of potential outflow sources these pools are often bordering and overlapping. The background is the orthophotomap completed with contour lines and chosen objects (roads, ways, watercourses, buildings) from topographic map.

Pools are put together into the sheet and displayed against topographic map background (Fig. 2). In the display scale, the difference is not so evident but in terms of next processing, this difference is important. The pools contour on the figure creates coherent polygon. This way created polygon represents the exposure zone caused by liquid outflow by the road transport.

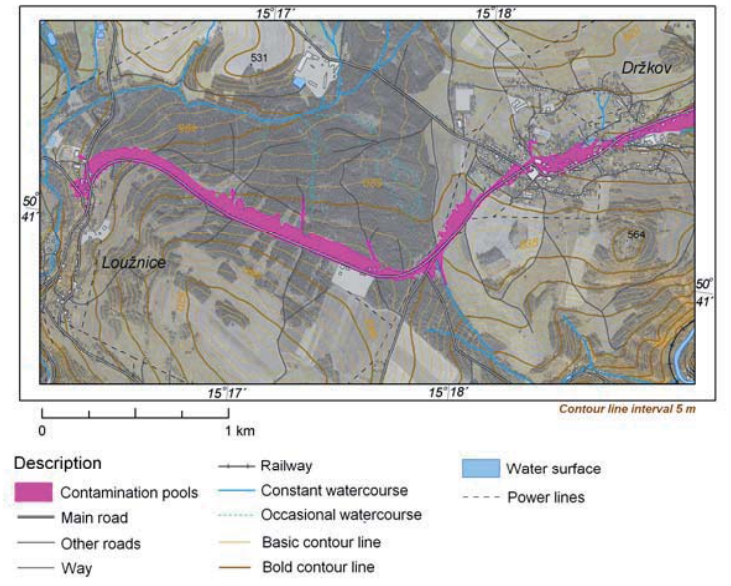

Fig. 1 Single pools incurred by outflow of $30 \mathrm{~m}^{3}$ fuel oil in the segment of the road E65 Loužnice Držkov

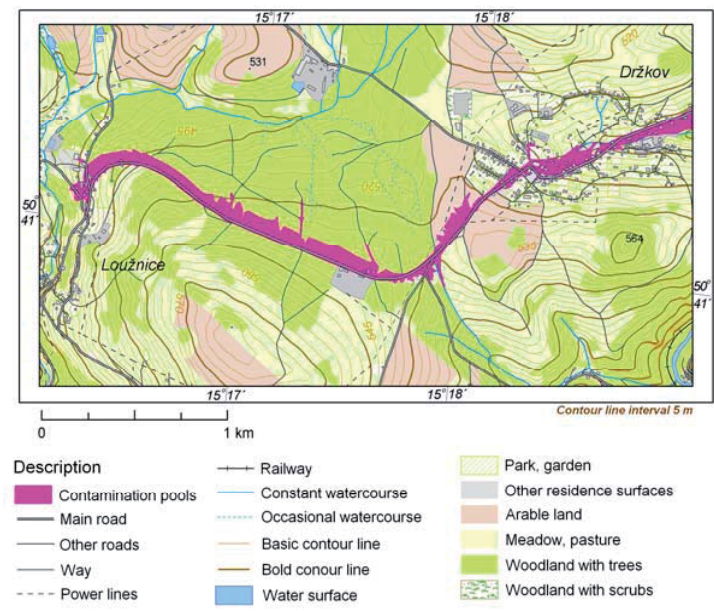

Fig. 2 Threatened zone for the transport of $30 \mathrm{~m}^{3}$ fuel oil in the segment of the road E65 Loužnice -

Držkov

On Fig. 3, 3D look on threatened area for sector Držkov - Plavy from south-west is displayed. It is evident how the form of threatened zone is dependent on the terrain morphology.

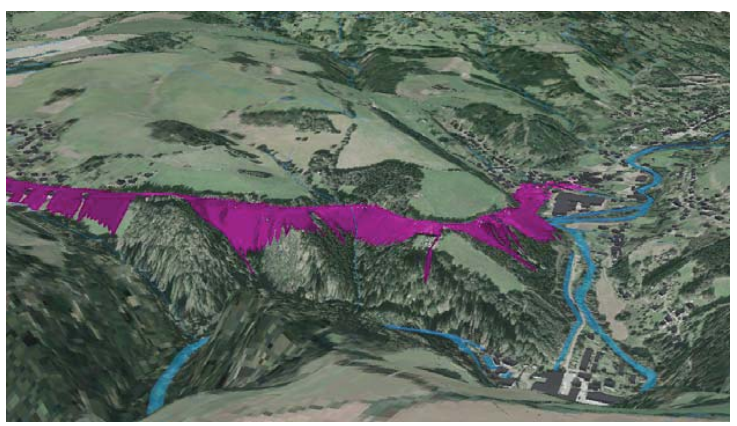

Fig. 3 The look on the threatened zone for the road segment Držkov - Plavy from south-west 


\section{The assessment of ecologic damage and social losses of the ecosystems service}

The assessment of biotopes biodiversity and their ecosystem services

Biotopes are covered in detail by the Methodology of Czech Republic biotopes evaluation, which was prepared for the Ministry of Environment in 2003 (Seják and Dejmal, 2003). This methodology identifies 192 biotopes types in total for the area of the Czech Republic and each square meter of the Czech Republic can be classified like some concrete biotope.

The method is based on expert generation of complete list of biotopes, which occur on the specific area. The catalogue of nature and nature close biotopes NATURA 2000 (Seják et al., 2010) was used in the Czech Republic. This catalogue was supplemented by an interdisciplinary team of ecologists about more anthropic affected biotopes (nature far biotopes, nature foreign biotopes and nature foreign biotopes with limited biota). The point value for each biotope was got based on interdisciplinary cooperation of different specialized ecologists. Expert pointing is based on the evaluation of eight following ecologic characteristics for each biotope. Each characteristic can get point value from one to six points:

1.Biotope type maturity [points according to phylogenetic age of formation and type],

2.Biotope type naturalness [6 points completely natural, 1 point completely anthropogenic],

3.Diversity of biotope type structure [6 point for all vegetation layer],

4. Diversity of biotope type species [points according to number of all naturally occurring species],

5. Biotope type rarity [points according to geographic and climatic uniqueness, rate and area],

6. Biotope type species rarity [points according to number of rare and endangered species],

7.Biotope type sensitivity (vulnerability) [points according to vulnerability degree due to habitat conditions],

8.Biotope type threat [points according to dependence on human activities change].

To get the biotope point value, the sum of points from the first four characteristics is multiplied by the sum of points from the second four characteristics and the resulting number is related to maximal possible number of points (576). This calculation formula enables to evaluate and order all biotopes according to their ecologic quality with relevant number of points in the range from three to hundred points.

The point value for each biotope is converted to money by points multiplying with average social costs of natural structures recovery, so with average national costs of one point. On the basis of representative analysis of 136 revitalizing projects, the point value of $12,36 \mathrm{CZK}$ was quantified in the Czech Republic till 2003. If we valorise the point value by inflation rate in the period of 2003 - 2008, then the value of one point is $14,50 \mathrm{CZK}$ in 2008 . So, the value of one point represents the costs for increase of biotope quality using revitalizing measures of 1 point. $\mathrm{m}^{-2}$.

The complete description of biotopes assessment method in the form of final report electronic book publication is possible to find on the website of Faculty of Environment of Jan Evangelista Purkyně University in Ústí nad Labem http://fzp.ujep.cz/Projekty/VAV610-5-01/HodnoceniBiotopuCR.pdf, brief description of the method with biotopes list then on the website http://fzp.ujep.cz/projekty/bvm/bvm_CZ.pdf.

Biotopes evaluation method sorts systematically all biotopes in the Czech Republic according to their ecological importance as well as specific environment for plants, animals, and microorganisms. Single selected biotopes and values of their examined parameters are shown in Tab. 1.

\section{Risk integration for environment elements along the traffic route}

The aim of integration is the evaluation of social risk of environment damage along the traffic route. The procedure of social risk calculation by dangerous liquid transport is methodically shown on Fig. 4. The result is a social risk of transport of one liquid load endangering environment elements. (CPR, 2005; Crowl and Louvar, 1990).

Within the solution, basic accident frequency by dangerous substance transport, separately for gases and liquids, was determined for each traffic route. The integration procedure is as follows:

1. The transport route is divided into segments, best per 10 - 20 meters.

2.For single segments, we determine modified frequencies according to local characteristics (villages, curves, straight segments).

3. We determine the quantity and kind of transported liquid. We expect the instantaneous outflow of the whole quantity and according to this we specify the defined outflow.

4. We specify characteristics of altimetry and objects, which should be taken into account by the calculation and we enter required parameters distribution. For every segment, the terrain sector is automatically selected, where the liquid will spread. 
Tab. 1 Values of biotopes and their environment providing for organisms, ecosystems annual services, ecosystems capital values and official price of territory in the Czech Republic in CZK.m² (Chytrý et al., 2001)

\begin{tabular}{|c|c|c|c|c|c|c|}
\hline Corine $L C$ classes & Points & $\begin{array}{l}\text { Biotopes } \\
\text { value } \\
\text { (BVM) }\end{array}$ & $\begin{array}{c}\text { Ecosys. } \\
\text { annual } \\
\text { services value }\end{array}$ & $\begin{array}{l}\text { Ecosystems } \\
\quad \text { value }\end{array}$ & $\begin{array}{c}\text { Official } \\
\text { prices Regul. } \\
\text { of MFČR }\end{array}$ & Note \\
\hline & Average & CZK.m. ${ }^{-2}$ & $\mathrm{CZK} \cdot \mathrm{m}^{-2}$ & CZK. $\mathrm{m}^{-2}$ & $\mathrm{CZK} \cdot \mathrm{m}^{-2}$ & \\
\hline 1.1.1. Consistent urban development & $0-2,4$ & $0-30$ & 669 & 13380 & $35-2250$ & By size of munic. \\
\hline 1.1.2. Inconsistent urban development & 10,2 & 126 & 1946 & 38920 & $35-2250$ & By size of munic. \\
\hline 1.2.1. Industry and business centres & $0-2,9$ & $0-33$ & 797 & 15940 & $35-2250$ & By size of munic. \\
\hline $\begin{array}{l}\text { 1.2.2. Road and railway network with its } \\
\text { surroundings }\end{array}$ & 8,2 & 100 & 1445 & 28900 & $35-2250$ & By size of munic. \\
\hline 1.2.3. Ports & 8,3 & 98 & 1747 & 34940 & $35-2250$ & By size of munic. \\
\hline 1.2.4. Airports & 11,9 & 148 & 1989 & 39780 & $35-2250$ & By size of munic \\
\hline 1.3.1. Areas of present mining of materials & 13,4 & 166 & 1080 & 21600 & $35-2250$ & By size of munic. \\
\hline 1.3.2. Heaps and landfills & 7,9 & 97 & 2476 & 49520 & 1 & \\
\hline 1.3.3. Construction site & 7,1 & 88 & 1055 & 21100 & $35-2250$ & By size of munic. \\
\hline 1.4.1. Urban green areas & 19,3 & 238 & 2659 & 53180 & $35-820$ & By size of munic. \\
\hline 1.4.2. Sport and recreation areas & 18,8 & 232 & 1986 & 39720 & $1-10$ & \\
\hline 2.1.1. Unirrigated arable land & 11,2 & 138 & 1552 & 31040 & $2-10$ & By districts \\
\hline 2.2.1. Vineyards & 15,2 & 188 & 2211 & 44220 & 42 & \\
\hline 2.2.2. Orchards, hop-gardens, plantations & 14,2 & 175 & 2205 & 44100 & 42 & \\
\hline 2.3.1. Meadows and pastures & 20,8 & 257 & 2562 & 51240 & $1-5$ & By districts \\
\hline $\begin{array}{l}\text { 2.4.2. Mixture of fields, meadows and } \\
\text { permanent crops }\end{array}$ & 14,1 & 174 & 2120 & 42400 & $1-10$ & By districts \\
\hline 2.4.3. Agricultural areas with natural vegetation & 21,5 & 266 & 2495 & 49900 & $1-5$ & By districts \\
\hline 3.1.1. Greenwoods & 40,7 & 503 & 3898 & 77960 & 30 & \\
\hline 3.1.2. Coniferous forests & 26,2 & 324 & 3112 & 62240 & 22 & \\
\hline 3.1.3. Mixed forests & 28,5 & 352 & 3270 & 65400 & 26 & \\
\hline 3.2.1. Natural pastures & 33,0 & 408 & 2721 & 54420 & 3 & \\
\hline 3.2.2. Steps and scrubs & 53,0 & 655 & 3220 & 64400 & 1 & \\
\hline 3.2.4. Transitions stages of forest and scrubs & 23,5 & 291 & 2660 & 53200 & 1 & \\
\hline 3.3.2. Rocks & 39,8 & 492 & 2680 & 53600 & 1 & \\
\hline 4.1.1. Wetlands and marches & 33,5 & 414 & 3968 & 79360 & 1 & \\
\hline 4.1.2. Peat bogs & 53,3 & 659 & 4201 & 84020 & 1 & \\
\hline 5.1.1. Watercourses & 23,1 & 286 & 3470 & 69400 & 7 & \\
\hline 5.1.2. Water surface & 18,7 & 231 & 3702 & 74040 & 7 & \\
\hline
\end{tabular}

5. Stochastic calculation of liquid spreading with random selection of parameters of altimetry, planimetry and liquid movement characteristics then follows. On figure 4, the relevant window is marked with the note ,1000 x Monte Carlo“. The number of variants can be selected randomly; it may be more or less than 1000 . The result of this calculation is a probability field of single points affection by outflow in every single segment. If we multiply these probabilities by modified accident frequency, we get the field of points affection frequencies, which are influenced by outflow in given segment.

$$
F(x, y)=\sum_{S} F_{S} \cdot P(x, y)_{S}
$$

where $F(x, y)$ is point affection frequency, $F_{S}$ accident frequency in s-th route segment, modified according to local conditions, $P(x, y)$ point $[x, y]$ affection probability by accident in $s$-th segment.

6. To every point, we assign the biotope, which occurs there, and then we determine the reduction of its value per $1 \mathrm{~m}^{2}$.

7. We multiply the loss in single points by the frequency of their affection. The sum of loss in single points represents total ecologic loss along the traffic route. 


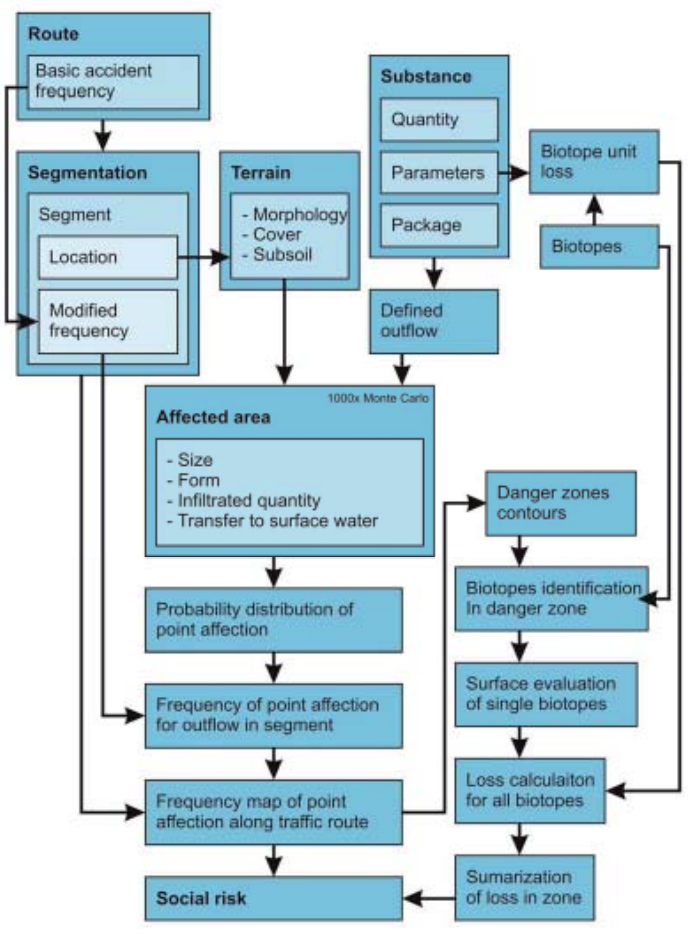

Fig. 4 Diagram of social risk assessment for biotopes

\section{Biotopes occurrence in danger zone}

The demonstration of biotopes occurrence according to CORINE LC in danger zone of leaked liquid can be seen on Fig. 5. The base is the orthophotomap of the area.

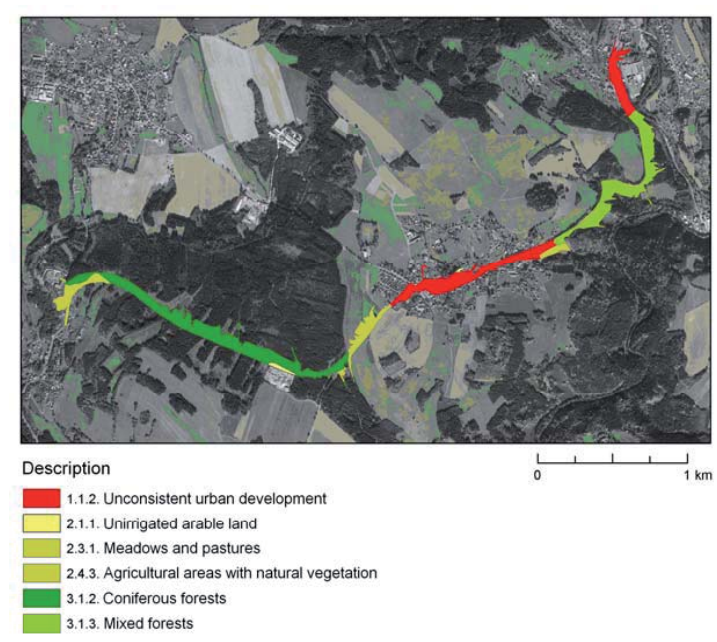

Fig. 5 Biotopes occurrence according to CORINE

LC in danger zone of leaked diesel oil in the segment of the road E65 Loužnice - Plavy
On Fig. 6, biotopes in the danger zone according to Natura 2000 BVM in the same area like on Fig. 5 are displayed. On the figure there are some large areas of incorrectly specified biotopes, marked like mosaic. Mosaic combines 2 or more different biotopes.

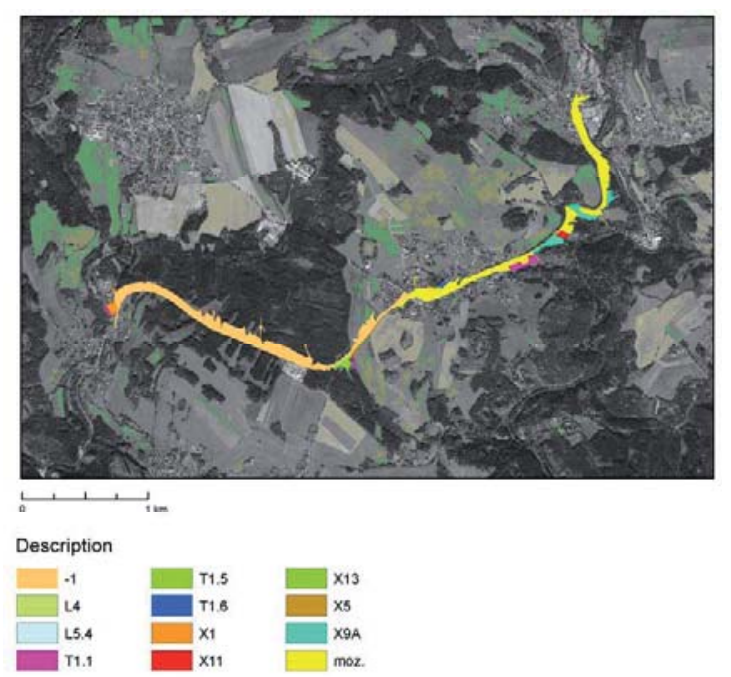

Fig. 6 Biotopes occurrence according to Natura BVM in danger zone of leaked diesel oil in the segment of the road E65 Loužnice - Plavy

\section{Biotope valuation in danger zone}

The list of biotopes, which occur in the danger zone of leaked liquid by transport of $30 \mathrm{~m}^{3}$ of diesel oil by the road E65 between Loužnice and Plavy, is summarized in Tab. 2. The annual point value, value of the degraded biotope after affection of leaked diesel oil and resulting unit loss are stated for all of them.

\section{Conclusion}

The exercise of liquid outflow is more difficult than for gases. Also the biotopes identification in the danger zone is more difficult than the assessment of population number from address points sets. Large complications come from data inconsistencies, which are not available for different areas. Detailed evaluation was done only for the segment of the road E65 between Loužnice and Plavy. Formulated procedures of identification will be necessary to verify also in different areas.

The valuation of biotopes in the danger zone along the road between Loužnice and Plavy was done with the usage of point and financial expression. The first attempt to risk calculation was done on the small road segment 400 meters long. Probabilities of point affection by leaked diesel oil in road closeness by 
accident in random $10 \mathrm{~m}$ segment of the road were calculated. Still no accident frequency was counted. This frequency may be modified according to local conditions (crossroad, curve). After the accident frequency evaluation in single route segments, it will be possible to determine the frequency of point affection in the danger zone.

\section{Acknowledgments}

This research was supported by the Ministry of the environment of the Czech Republic, project No. TA01030833 - Integrated information system for road transportation of dangerous chemicals

Tab. 2 The list of biotopes in the threatened zone

\begin{tabular}{|c|c|c|c|c|c|c|}
\hline \multirow{2}{*}{$\begin{array}{c}\text { BIOTOPE } \\
\text { NATURA 2000 }\end{array}$} & \multirow[t]{2}{*}{ BVM } & & \multirow{2}{*}{\begin{tabular}{|c|}
$\begin{array}{c}\text { BVM } \\
\text { default }\end{array}$ \\
Points \\
\end{tabular}} & \multirow[t]{2}{*}{$\begin{array}{l}\text { Type of biotope } \\
\text { after degradation }\end{array}$} & \multirow{2}{*}{\begin{tabular}{|c|}
$\begin{array}{c}\text { BVM } \\
\text { degradation }\end{array}$ \\
Points \\
\end{tabular}} & \multirow{2}{*}{$\begin{array}{l}\text { Point loss } \\
\text { Points } / \mathrm{m}^{2}\end{array}$} \\
\hline & & & & & & \\
\hline L2.2B & $\mathrm{L} 2.2 \mathrm{~B}$ & Valley ash-alder wetlands & 42 & $\mathrm{XL3}$ & 20 & 22 \\
\hline $\mathrm{L} 4$ & $\mathrm{~L} 4$ & Ravine forests & 42 & $\mathrm{XL3}$ & 20 & 22 \\
\hline L5.4 & L5.4 & Acidophilous beech forests & 38 & $\mathrm{XL3}$ & 20 & 18 \\
\hline S1.2 & S1.2 & $\begin{array}{l}\text { Crevice vegetation of silicate rocks } \\
\text { and offal }\end{array}$ & 46 & XS1-2 & 12 & 34 \\
\hline T1.1 & T1.1 & Mesophilic tall oatgrass meadows & 33 & XT3 & 15 & 18 \\
\hline T1.5 & T1.5 & Wet thistle meadows & 49 & $\mathrm{XT2}$ & 17 & 32 \\
\hline T1.6 & T1.6 & Wet meadowsweet fallow & 46 & XT2 & 17 & 29 \\
\hline $\mathrm{X} 1$ & $\times 5.2 / \times \times 3.1$ & $\begin{array}{l}\text { Utility garden and gardening colonies / } \\
\text { developed area with minimal vegetation }\end{array}$ & 8,4 & $X X 4.2$ & 0 & 8,4 \\
\hline $\mathrm{X} 12$ & $\mathrm{XK2}$ & Fallow with scrug vegetation and trees & 24 & $\mathrm{X} 4.5$ & 10 & 14 \\
\hline $\mathrm{x} 13$ & XL1 & $\begin{array}{l}\text { Hedgerows, alleys and line trees } \\
\text { vegetation in landscape }\end{array}$ & 25 & $\times 4.5$ & 10 & 15 \\
\hline $\mathrm{X} 14$ & $\mathrm{XV4}$ & Locally modified watercourses & 23 & $\mathrm{X} 1.4$ & 6 & 17 \\
\hline$\times 5$ & XT3 & $\begin{array}{l}\text { Intensive or degradated mesophilic } \\
\text { meadows }\end{array}$ & 13 & $\times 4.5$ & 10 & 3 \\
\hline X6 & XT6 & $\begin{array}{l}\text { New mining spaces and heaps of } \\
\text { natural substrates }\end{array}$ & 13 & $\times 4.7$ & 6 & 7 \\
\hline$\times 7$ & XT3 & $\begin{array}{l}\text { Intensive or degradated mesophilic } \\
\text { meadows }\end{array}$ & 13 & $\times 4.5$ & 10 & 3 \\
\hline $\mathrm{X} 11$ & XL5 & $\begin{array}{l}\text { Clearings, forest after planting and } \\
\text { renaturalization planting }\end{array}$ & 20 & $\times 4.5$ & 10 & 10 \\
\hline X9A & $\mathrm{XL4}$ & $\begin{array}{l}\text { Monocultures of habitat inappropriate } \\
\text { timbers }\end{array}$ & 20 & $\times 4.5$ & 10 & 10 \\
\hline
\end{tabular}

\section{References}

Committee for the Prevention of Disasters (CPR), Directorate-General of Labour of the Ministry of Social Affairs. (2005). Methods for the Calculation of Physical Effects Resulting from Releases of Hazardous Materials (Liquids and Gases), (Yellow Book), 3rd ed., The Hague, 2005, CPR 14E.

CROWL, D. A., LOUVAR, J. F. (1990). Chemical Process Safety: Fundamentals with Application, PTR PrenticeHall Inc., A. Simon \& Schuster Company, Englewood Cliffts, New Jersey, 1990.

CHUDOVÁ, D., BLAŽKOVÁ, K. (2007). Přeprava nebezpečných látek z pohledu havarijního plánování území. Sborník vědeckých praci Vysoké školy báňské - Technické univerzity Ostrava, Řada bezpečnostního inženýrství, 2007, ročník LIII, č. 1. ISSN 1801-1764. (in Czech)

CHYTRÝ, M., KUČERA, T., KOČÍ, M. (2001). Katalog biotopů České republiky. Praha: Nature Conservation Agency of the Czech Republic, 2001. 307 s. ISBN 80 -86064 -55 -7 (in Czech).

KONTULA, T., RAUNIO, A. (2009). New method and criteria for national assessments of threatened habitat types. Biodiversity and Conversation. 2009, Volume 18, Isuue 14, p. 3861 - 3876. ISSN 09603115. 
SASKA, T., NOVÁK, J., ŠMÍDA, J., HAVLÍČEK, J., SOUŠEK, R. (2010). GIS software tools application for dangerous goods transport risk evaluation. In: Proceedings of the Reliability, Risk and Safety - "ESREL". Rhodes, 2010. ISBN 978-0-415-60427-7.

SEJÁK, J., DEJMAL, I., et al. (2003). Hodnocení a oceňování biotopů České republiky. Praha: Czech Ecologic Institute, 2003. 422 p. ISBN 80-85087-54-5 (in Czech).

SEJÁK, J., et al. (2010): Hodnoceni funkci a služeb ekosystémů České republiky. Ústí nad Labem: Faculty of environment, J.E.Purkyně University in Ústí nad Labem, 2010. 197 s. ISBN 978-80-7414-235-2 (in Czech).

SIMMONS, C. S., KELLER, J. M. (2003). Status of Models for Land Surface Spills of Nonaqueous Liquids [online]. Pacific Northwest National Laboratory, Richland, 2003. Available at: http://www.pnl.gov/main/ publications/external/technical_reports/PNNL-14350.pdf.

SIMMONS, C. S., KELLER, J. M. (2005). The Influence of Selected Liquid and Soil Properties on the Propagation of Spills Over Flat Permeable Surfaces [online]. Pacific Northwest National Laboratory, Richland, 2005. Available at: http://www.pnl.gov/main/publications/external/technical_reports/PNNL-15058.pdf. 